\begin{tabular}{|c|c|c|}
\hline \multirow[t]{2}{*}{ 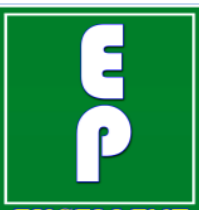 } & $\begin{array}{l}\text { International Journal of Current Research in } \\
\text { Biosciences and Plant Biology }\end{array}$ & \\
\hline & Volume $4 \bullet$ Number 8 (August-2017) • ISSN: 2349-8080 (Online) & \\
\hline $\begin{array}{l}\text { EXCELLEN } 1 \\
\text { PUBLISHERS }\end{array}$ & Journal homepage: www.ijcrbp.com & wwewilichp. com \\
\hline
\end{tabular}

\title{
Moringa oleifera: A Miracle Multipurpose Potential Plant in Health Management and Climate Change Mitigation from Bahraich (UP) India - An Overview
}

\author{
T.P. Mall* and S.C. Tripathi
}

Postgraduate Department of Botany, Kisan PG College, Bahraich, Uttar Pradesh-271 801, Indi0061

*Corresponding author.

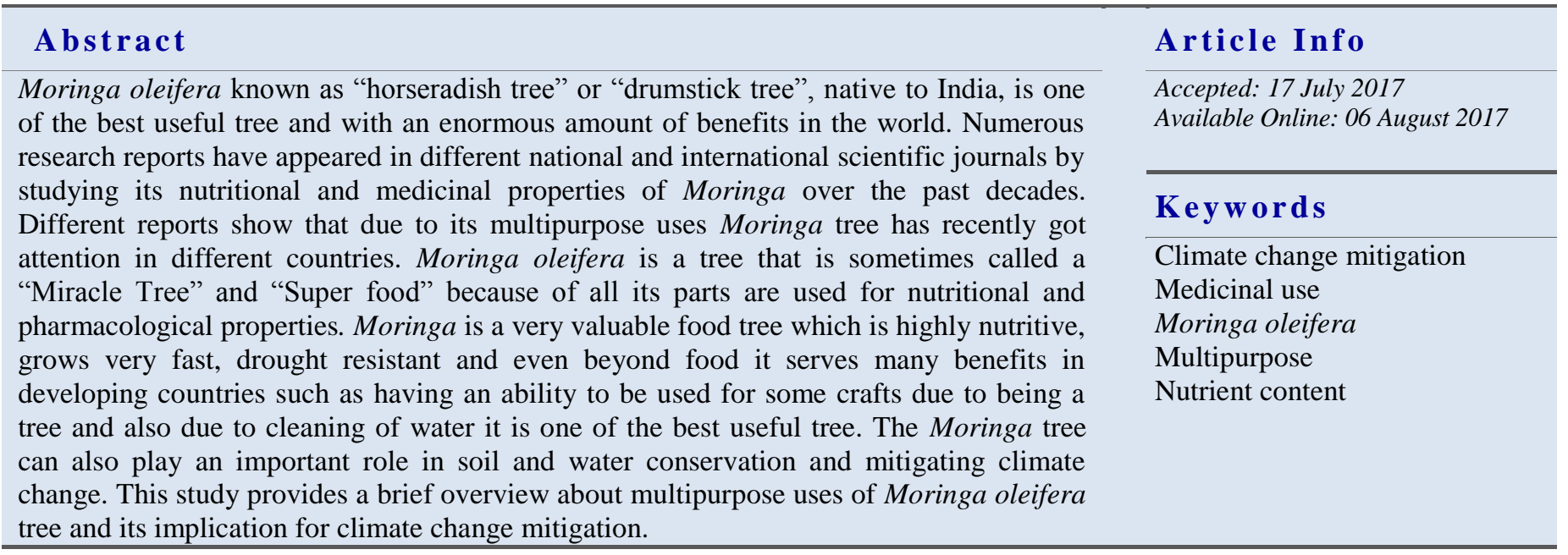

\section{Introduction}

Moringa oleifera Lam. (Synonym: Moringa pterygosperma Gaertner) belongs to a monogeneric family of shrubs and tree, Moringaceae and is considered to have its origin in Agra and Oudh, in the northwest region of India, south of the Himalayan Mountains. Although the name "Shigon" for M. oleifera is mentioned in the "Shushruta Sanhita" which was written in the beginning of the first century A.D., there is evidence that the cultivation of this tree in India dates back many thousands of years. The use of plants and their constituents in primary health care has ancient history as old as human beings. Various medicinal plants has proven therapeutics implication in the health management via antioxidant, anti-inflammatory, antidiabetic, and other biological activities. The consequence of herbs has been also stated in the different religious book. In Islam, the importance of herbs in health care has been discussed in details and Prophet Mohammed recommended several plants, fruits and seed for the cure of various diseases (Rahmani, 2015). The people of India knew that the seeds contain edible oil and they used them for medicinal purposes. It 
is probable that the common people also knew of its value as a fodder or vegetable. This tree can be found growing naturally at elevations of up to $1,000 \mathrm{~m}$ above sea level. It can grow well on hillsides but is more frequently found growing on pasture land or in river basins. It is a fast growing tree and has been found to grow to 6-7 $\mathrm{m}$ in one year in areas receiving less than $400 \mathrm{~mm}$ mean annual rainfall (Odee, 1998).

In the Dravidian language, there are many local names for this tree but all are derived from the generic root "Morunga". In English it is commonly known as Horseradish tree, Drumstick tree, Never Die tree, West Indian Ben tree, and Radish tree (Ramachandran et al., 1980). It is now cultivated throughout the Middle East, and in almost the whole tropical belt. It was introduced in Eastern Africa from India at the beginning of $20^{\text {th }}$ century. In Nicaragua the Marango (local name for Moringa oleifera) was introduced in the 1920 s as an ornamental plant and for use as a live fence. The tree grows best and is most commonly found in the Pacific part of Nicaragua but can be found in forest inventories in every part of the country. As a non-cultivated plant it is known for its resistance to drought and diseases. Because this tree has so many potential uses, there have been conducting an extensive research program on it over the last ten years in many countries including India. The plant possesses many valuable properties which make it of great scientific interest. These include the high protein content of the leaves, twigs and stems, the high protein and oil contents of the seeds, the large number of unique polypeptides in seeds that can bind to many moieties, the presence of hormones in the leaves, and the high sugar and starch content of the entire plant. Equally important is the fact that few parts of the tree contain any toxins that might decrease its potential as a source of food for animals or humans.

Moringa oleifera commonly referred to as the 'drumstick tree' (describing the shape of its pods) or 'horseradish tree' (describing the taste of its roots), it is a multi-purpose tree of significant economic importance with several industrial and medicinal uses (CSIR, 1962; Baumer, 1983). It is a small tree $(7 \pm 12 \mathrm{~m}$ high) with thick grey bark, fragrant white flowers and long green pods which give the tree its name. Oil is extracted from the seeds or the seeds are used in curry powders. The fruits, seeds, leaves and flowers are also eaten as nutritious vegetables in some countries. The leaves are rich in carotene, iron and ascorbic acid and the pods in free leucine (CSIR, 1962; Chawla et al., 1988).
Arora et al. (2013) has reported that there are about 33 species of Moringaceae family. Moringa oleifera is one of the Moringaceae family. M. arborea, M. borziana, $M$. concanensis, $M$. drouhardi, M. hildebrandtii, $M$. longituba, M. oleifera, M. ovalifolia, M. peregrina, M. pygmaea, $M$. rivae, $M$. ruspoliana and $M$. stenopetala are well known and found worldwide. Numerous studies have reported its multipurpose use like medicinal and nutritional benefits (Dahot, 1988; Anwar et al., 2013). Moringa tree due to its medicinal and nutritional properties in world is described as a 'miracle tree' (Fuglie, 2003; Amaglo, 2006; Yisehak et al., 2011; Ashfaq et al., 2012). Moringa oleifera is the most promising tree which has been used for nutritional benefits, medicinal properties and environmental conservation. Moringa oleifera is reputedly known as "cabbage tree", "drumstick tree" or "horseradish tree", 'ben-oil tree' or 'benzoil tree', 'miracle tree' and 'mother's best friend tree' (Koul and Chase, 2015). As reported by different scholars Moringa oleifera has wide range of uses. Among those, water purification, human consumption, medicine, fuel wood, dye, conservation, livestock forage and green manure (Demeulenere, 2001; Palada and Chang, 2003; Jiru et al., 2006; ECHO, 2009; Melesse et al., 2011).

According to Dawit et al. (2016), Moringa has multipurpose use, well adapted and significant economic importance, as it has vital nutritional, industrial, and medicinal applications. Application of eighty percent ethanol extract of $M$. oleifera leaves been shown to increase nodulation of black-gram (Vigna mungo L.) considerably (Bose, 1980). The kernels of M. oleifera can be crushed and its water extract used for the purification of water (Holmes et al., 1994).

The water extract is considered to be a viable replacement coagulant for chemicals such as aluminium sulphate (alum) in developing countries. As Moringa oil can be used for human consumption, the water extract of seed meal (obtained after extraction of the oil) has been used to purify water. Large scale cultivation of $M$. oleifera has been initiated in Malawi, Nicaragua and India to make use of the leaves for the extraction of growth hormones, and of the kernels to extract oil for human consumption and for the purification of water (Tauscher, 1994). The present study may pave the way for better utilization of different fractions residues of the $M$. oleifera tree, which are generated as by-products in the process of extraction of 
oil, growth hormones and coagulants, as animal feed.

The Moringa tree can play an important role in soil and water conservation and mitigating climate change. As reported by researchers in different countries, all parts of Moringa oleifera viz., leaves, fruits, immature pods, and flowers are combined into the traditional food for human consumption (Siddhraju and Backer, 2003; Anhwange et al., 2004).

According to Anhwange et al. (2004) in many parts of the Africa the Moringa oleifera is used as a food. For example, dried Moringa leaves and fresh Moringa are involved in meals in several African countries. The seed of Moringa oleifera is also used for water treatment as water purification and remove bacteria from water up to 99\% as indicated (Foidl et al., 2001; Villafuerte, 2009). According to Foidl et al. (2001) from the Moringa fresh leaves juice can be extracted and used as a growth hormone that can increase yields of crop by $25-35 \%$.

As indicated by Amaglo (2013), famine is connected to climate change and therefore, planting trees, which can sequester more carbon like Moringa tree, can play important role in climate change mitigation. There is an urgent need to implement climate smart policies that can be built more silient food systems and combat climate change. There is great potential for the Moringa tree to not only store carbon, if it is grown on a much larger scale, but to improve the livelihoods of many farmers (Gedefaw, 2015). This study provides a brief over view about multi purpose uses of Moringa oleifera tree and its implication for Climate Change Mitigation. The purpose of this brief review is: to assess the published scientific journals suggestion on multipurpose uses of Moringa oleifera; to over view its medicinal and nutritional properties; to suggest future directions for policies, research, market and development strategies and finally to review its implication for climate change mitigation.

\section{The plant morphology}

The stem is normally straight. The tree grows with a short, straight stem that reaches a height of three meter before it begins branching. The extended branches grow in a disorganized manner and the canopy is umbrella shaped (Foidl et al., 2001).

The leaves are alternate, twice or thrice pinnate leaves grow mostly at the branch tips. They are $20-70 \mathrm{~cm}$ long, grayish-downy when young, long petiole with 8-10 pairs of pinnae each bearing two pairs of opposite, elliptic or obovate leaflets and one at the apex, all 1-2 cm long; with glands at the bases of the petioles and pinnae (Morton, 1991).

The flowers, which are pleasantly fragrant, and $2.5 \mathrm{~cm}$ wide are produced profusely in axillary, drooping panicles 10 to $25 \mathrm{~cm}$ long. They are white or cream colored and yellow-dotted at the base. The five reflexed sepals are linear-lanceolate. The five petals are slenderspatulate. They surround the five stamens and five staminodes and are reflexed except for the lowest (Morton, 1991).

The fruits are three lobed pods which hang down from the branches and are 20-60 $\mathrm{cm}$ in length. When they are dry they open into 3 parts. Each pod contains between 12 and 35 seeds.

The seeds are round with a brownish semi-permeable seed hull. The hull itself has three white wings that run from top to bottom at 120-degree intervals. Each tree can produce between 15,000 and 25,000 seeds/year. The average weight per seed is $0.3 \mathrm{~g}$ and the kernel to hull ratio is $75: 25$ (Makkar and Becker, 1997).

The average weight of pods are eight gm where as weight of seeds per pod is four gm, seeds per pod eleven, weight of hundred seeds is thirty gm, weight of hundred seeds kernel twenty two gm It is a good source of provitamin A, vitamins $\mathrm{B}$, and $\mathrm{C}$, minerals particularly iron, and the sulphur-containing amino acids. The composition of the amino acids in the leaf protein is well balanced (Foidl et al., 2001). The significant Micro mineral elements are Calcium, Phosphorus, Magnesium, Sodium, and Potassium whereas micro elements are Iron, Mangnese, Zinc and Copper.

The carotenoids present in leaves are alpha-carotene, beta-carotene, lutein, eoxanthin, violaxanthin, zeaxanthine, xanthophyll, carotenoids and chlorophylls with high physico-chemical properties like saponification value 182.9 , iodine value 66.4 , density at $20^{\circ} \mathrm{C}(\mathrm{g} / \mathrm{ml}) 0.89737$, refractive index at $20^{\circ} \mathrm{C} 1.46 .70$, solidification point (pour point ${ }^{\circ} \mathrm{C}$ ) 6 and free fatty acids (\%) up to 2.98. The percentage of fatty acid composition of Moringa seed oil are lauric acid in traces, myristic 0.08 , penadecanoic trace, palmmitic 5.45, palmitoleic 1.48 , margeric 0.08 , margaroleic 0.05 , stearic 5.42 , oleic (18-1) 72.9, linoleic 0.76, linolenic 0.14, archidic 3.39, 
gadoleic 2.2 , behanic 6.88 , erucic 0.14 , lignoceric 0,92 , and nurvonic acid in trace (Foidl et al., 2001).

\section{Amino acid composition of Moringa leaves}

- The amino acid content $(\mathrm{g} / 16 \mathrm{~g} \mathrm{~N})$ of un-extracted leaves is lower than that of extracted leaves which is due to the presence of a higher amount of non protein nitrogen in the un-extracted leaves (4.7 vs $2.7 \%$ ). The potential food value of the protein (as a source of amino acids) can be evaluated by comparison with the FAO reference pattern (Zarkadas et al., 1995). All essential amino acids are higher than adequate concentrations when compared with the recommended amino acid pattern of the FAO/WHO/UNO reference protein for 2 to 5 year old children.

- The amino acids present are lycine, leucine, isoleucine, methionine, cystine, phenylalanine, tyrosine, valine, histidine, threonine, serine, glutanic acid, aspartic acid, proline, glycine, alanine, arginine, and tryptophan.

\section{Moringa parts and their uses}

- Stem-animal feed

- Twig-animal feed

- Leaves-animal feed, growth hormones, human consumption, and medicinal uses

- Bark-dyes, tannins, and medicinal uses

- Roots-medicinal uses, and human consumption

- Pods-medicinal uses, and human consumption

- Seeds-seed shells are used as fuel whereas kernels oil is used for cooking, cosmetics, medicinal and industrial uses, meal obtained after oil removal is extracted meal used as animal feed and meal coagulants are used in water purification.

\section{Ethnobotanical potential}

\section{Human consumption of Moringa:}

\section{Nutrient contents of Moringa oleifera}

- The most amazing fact about Moringa is that it is a storehouse of nutrients and medicinal chemicals (Jongrungruangehok et al., 2016 and Moyo et al., 2011). Moringa tree is rich in nutrients such as minerals, fiber and proteins that can play essential role in human nutritional consumption. It has been shown that Moringa oleifera leaves has high protein compared to with other leaves eaten as food.

- A recent research on dietary iron supplements and Moringa oleifera leaves influence the liver revealed that iron from Moringa oleifera can overcome iron deficiency (Saini et al., 2014).

- Moringa is full of vitamins, nutrients and therefore, it is good to have as food for human consumption and as food for animal's consumption. It is also reported that Moringa seeds contain about $30-40 \%$ oil, $82 \%$ unsaturated fatty acids and $13 \%$ saturated fats (Villafuerte, 2009).

- There are multipurpose uses of most parts of Moringa oleifera in making food for human consumptions such as cake (Kolawole et al., 2013), Yoghurt (Salem et al., 2013; Kuikman Conner, 2015; Hekmat et al., 2015). Amla (Karim et al., 2013; Karim et al., 2015), weaning foods (Arise et al.,2014), bread (Chinma et al., 2014), soups (Stevens et al., 2013; Babayeju et al., 2014), and biscuits (Alam et al., 2014).

- The potential uses of Moringa oleifera shows that, Moringa contain nutritional value and can be used as bread, milk, spices, juices, sauces and tea (Rockwood et al., 2013).

- Moringa oleifera is a wonderful food tree with a significant source of vitamin $\mathrm{C}$, calcium, proteins and Iron. Rockwood et al. (2013) has confirmed that, Moringa oleifera dry leaves contain nine times more proteins than yogurt whereas ten times vitamin A than carrot, twenty five times iron than spinach, fifteen times potassium than bananas, seventeen times calcium than milk and seven times more vitamin $\mathrm{C}$ than orange. Because of rich in proteins source Moringa oleifera leaves are suggested by doctors, nutritionists.

- All parts of Moringa oleifera viz., leaves, fruits, immature pods, and flowers are combined into the traditional food for human consumption (Siddhraju and Backer, 2003; Anhwange et al., 2004). Many parts of the Africa use Moringa oleifera as a food. Dried Moringa leaves and fresh Moringa are involved in meals in countries such as Ethiopia, Nigeria, Malawi, East Africa and Ghana (Anhwange et al., 2012).

- The young leaves are edible and commonly cooked and eaten like spinach or used to make soups and salad.

- The young green pods are very tasty and can be boiled and eaten like green beans. The pods are 
best at the stage when they can be broken easily. These are rich in free amino acids like leucine.

- The seeds should be eaten when they are green before they change their color to yellow and should be boiled for few minutes to remove the fine transparent hull and the water is drained before they are consumed. The hull is not desirable as food because it is bitter in taste.

- The dry seeds can be ground to a powder and used for seasoning sauces.

- The roots from young plants can also be dried and ground for use as a hot seasoning base with a flavor similar to that of horseradish. This is why the Moringa tree has been given the name "Horseradish Tree" (Delaveau and Boiteau, 1980).

- A tasty hot sauce from the roots can also be prepared by cooking them in vinegar.

- The flowers can be eaten after being lightly blanched or raw as a tasty addition to salads.

- The resin from the trunk of the tree is also useful for thickening sauces.

\section{Socio-economic importance}

- Moringa is one of the most useful tropical trees. The relative ease with which it propagates through both sexual and asexual means and its low demand for soil nutrients and water after being planted make its production and management easy. Introduction of this plant into a farm which has a biodiverse environment can be beneficial for both the owner of the farm and the surrounding eco-system. It is a fast growing perennial tree with seven-twelve meter height.

\section{Industrial uses of Moringa oil}

- The oil content of kernel is approximately $42 \%$. The oil is brilliant yellow. It is used as a lubricant for fine machinery such as time pieces because it has little tendency to deteriorate and become rancid and sticky (Ferrao and Ferrao, 1970; Ramachandran et al., 1980).

- It is also useful as vegetable cooking oil.

- The oil is known for its capacity to absorb and retain volatile substances and is therefore, valuable in the perfume industry for stabilising scents. The free fatty acid content varies from 0.5 to $3 \%$. The seed oil of Moringa contains approximately $13 \%$ saturated fatty acids and $82 \%$ unsaturated fatty acids. It has a particularly high level of oleic acid (70\%). Other vegetable oils normally contain only about $40 \%$ oleic acid.

\section{$>$ Moringa for water purification}

- The study on the Moringa oleifera as a natural gift point out that, a billion people across world like; Latin America, Africa, and Asia are assessed to depend on untreated water sources for their daily needs (Mahmood et al., 2010). Numerous research reports shown that, Moringa seed powder can be used cleaning dirty water in simple and quick method. The Moringa seed powder joins with the solids in the dirty water and sinks to the bottom. This action can remove bacteria contained in water up to $90-99 \%$. Rather than using aluminum sulphate, which are dangerous to people and the environment. Using Moringa seed powder to purify water is cheap. Water can be purified by adding two grams of Moringa seed powder to twenty liters into a bottle and shake for five minutes. Dirty water that is to be treated can be filtered through a clean cloth into the container. Until the water becomes clear and the impurities have sunk to the bottom leave the bucket undisturbed for one hour then filter the water through a clean cloth boil the water before drinking (Francis and Jieyier, 1991; Jahn et al., 1986; Sutherland et al., 1989; Gassensechmidt, 1995).

- Moringa seeds contain between 30-42\% oil and the press cake obtained as a by-product of the oil extraction process contains a very high level of protein. Some of these proteins (approximately $1 \%)$ are active cationic poly-electrolytes having molecular weights between 7-17 K Dalton. The cationic polyelectrolytes neutralize the colloids in muddy or dirty water since the majority of these colloids have a negative electrical charge. This protein can therefore, be used as a non-toxic natural polypeptide for sedimenting mineral particles and organics in the purification of drinking water, for cleaning vegetable oil, or for sedimenting fibers in the juice and beer industries. It thus works as a primary coagulant as natural bridges are continuously formed between the colloid particles.

- The wings are removed from the dry seeds and then the seeds are ground to powder. The powder is mixed with water, agitated for approximately five minutes and after about an hour it is filtered through a piece of woven fabric to obtain pure water.

- Alternatively, a cloth containing the seed powder 
is suspended in water, generally overnight, to coagulate impurities. The cloth containing the seeds is then removed, and the purified water is decanted leaving behind the coagulated particles on the bottom. Only one seed is required per litre for slightly contaminated water and two seeds for very dirty water.

\section{$>\quad$ Moringa as plant growth enhancers}

- The extract obtained from the Moringa leaves in $80 \%$ ethanol contains growth enhancing principles like cytokinine. The extract can be used in the form of a foliar spray to accelerate the growth of young plants. Use of the growth hormone spray will also cause the plants to be firmer and more resistant to pests and disease. Plants that are treated with this growth hormone spray will also produce more and larger fruit and will consequently have a higher yield.

- The extract can be obtained either through press extraction or by using an ultra-turrax and filtering $20 \mathrm{~g}$ of tender leaves in a total volume of $675 \mathrm{ml}$ of $80 \%$ aq. ethanol (Makkar and Becker, 1996).

- Spraying the leaves of plants with the Moringa extract prepared in $80 \%$ ethanol and then diluted with water produced some notable effects such as a longer, more vigorous life-span, heavier roots, stems and leaves, bigger fruits and higher sugar levels etc. The extract produces an overall increase in yield of between 20-35 \% based on data such as the stem diameter, number of nodules, number of axels, number of flower buds, and number of fruits per flower bud.

\section{$>\quad$ Moringa as a source of biogas}

- Moringa plants (approximately 30 days old) were milled together with water. The fibre was separated by filtration through a mesh with $5 \mathrm{~mm}$ pores and the liquid fraction produced was then added to a biogas reactor. With an average feed of $5.7 \mathrm{~g}$ of volatile solids the gas production was 580 liters of gas per $1 \mathrm{~kg}$ of volatile solids. The average methane content of the gas was eighty one percent.

\section{Moringa as a forage plant}

- The nutritional characteristics of the Moringa tree are excellent so it can easily be used as a fresh forage material for cattle. The leaves are rich in protein, carotene, iron and ascorbic acid and the pod is rich in the amino acid lysine (CSIR, 1962; Chawla et al., 1998; Dogra et al., 1975). Another important advantageous characteristic of Moringa is its high productivity of fresh material per unit area compared with other forage crops.

\section{$>$ Animal feed fortification}

- Study on the potential of Moringa oleifera for agricultural and industrial uses and on the naturalized exotic tree species shown that, Moringa leaves supplementary to livestock feed can increase up to $32 \%$ of daily weight gain. Supplementation of fresh Moringa leaves with 15 to $17 \mathrm{~kg}$ of daily feed of livestock can increase milk production by $43 \%$. Milk production can be increased by $58 \%$ with the supplementation of $2 \mathrm{~kg}$ dry matter feed and milk production increased by $65 \%$ with the supplementation of $3 \mathrm{~kg}$ dry matter feed (Foidl et al., 2001 and Adeyemi and Elebiya, 2014). Generally, milk production increased with increased Moringa supplementation.

\section{Moringa kernel and meal as animal feed}

- The kernels of Moringa can be crushed and its water extract used for purification of water, and the water extract is a viable replacement coagulant for chemicals such as aluminium sulphate (alum) in developing countries.

- Moringa oil can be used for human consumption, the water extract of seed meal which is obtained after extraction of oil has been used to purify water. This residue is still active as a coagulant. The chemical constituents, organic matter digestibility, gross and metabolizable energies, rumen degradable and un degradable nitrogen, non-protein nitrogen, pepsin degradability of proteins and presence of anti nutritional factors in kernels, seed meal (fat-free kernel) and in the residues obtained after removal of water soluble coagulants from kernels and seed meal obtained from the Moringa plant (Foidl, 2001). Amino acid composition of these four fractions of kernels has also been analysed (Makkar and Becker, 1997). This information together with reported above for the Moringa forage will pave the way for better utilization of different fractions/residues of Moringa, which are generated as by-products in 
the process of extraction of oil, growth hormones and coagulants, as animal feed.

$>$ Production level of fresh green matter in Moringa plantations

- A study consisting of many trials was completed to discover the optimum density at which Moringa should be planted to produce a maximum amount of fresh green matter (Foidl et al., 2001). The final density and hence the number of plants eliminated depends on the specific production goals. If for example the goal is to produce green fodder with a maximum of protein and a minimum of lignin then cutting should be done every 33 to 40 days. If instead the goal is to produce a maximum of lingo-cellulose fibers for paper production, the ideal cutting time would be after 6 to 8 months of growth. This amount of time would enable the trunk of the plant to reach the necessary diameter and for the percentage of leaves, small branches and bark to be reduced thereby optimising the percentage of lignified wood.

- Since Moringa continues to grow between cuttings the number of plants per hectare is dramatically reduced owing to the different growth rates among the plants. As they compete for sunlight the larger plants shade out the slower growing or smaller plants. At 35 days, the average height of the plants is still between 1.6 and 2.0 meters and so the competition for light is not yet very great. Differences in height between plants at this stage range between 10 and $40 \mathrm{~cm}$.

\section{$>$ Uses of Moringa}

- Moringa leaves are a storehouse of nutrients. The leaves of Moringa oleifera are rich in minerals like copper, potassium, iron, magnesium, zinc and calcium (Kasolo et al., 2010). Vitamins like betacarotene of vitamin A, vitamin B such as folicacid, pyridoxine and nicotinic acid, vitamin $\mathrm{C}, \mathrm{D}$ and $\mathrm{F}$ also presentin Moringa oleifera (Mbikay, 2012). Yameogo et al. (2011) also reported that, on a dry matter basis, Moringa oleifera leaves contained $27.2 \%$ protein, $17.1 \%$ fat, $5.9 \%$ moisture and $38.6 \%$ carbohydrates. Anwar and Rashid, (2007) noticed that on a dry matter basis, Moringa oleifera seeds contained $34.80 \%$ ether extract, $31.65 \%$ protein, $7.54 \%$ fiber, $8.90 \%$ moisture, and $6.53 \%$ ash contents. Makkar and Becker, 1997).
- Moringa seed contains antibiotic (pterygospermin), fatty acids like linolenic acid, linoleic acid, behenic acid and oleic acid (Ben oil); Phytochemicals like saponin, tannins, phytate, phenolics, terpenoids, flavonoids and lectins. Apart from these it contains, fiber, fats, minerals, proteins, and vitamins like $\mathrm{A}, \mathrm{B}, \mathrm{C}$ and amino acids (Rockwood et al., 2013, Thurber and Fahey, 2010, Mibikay, 2012; Nair and Varalaxami, 2011; Sutalangka et al., 2013). The Moringa pods rich in lipids, fiber, non-structural carbohydrates, ash and protein. It also contains fatty acids like linoleic acid, oleic acid, palmitic acid and linoleic acid (Rockwood et al., 2013 and Thurber and Fahey, 2010).

- There are many uses of Moringa tree viz., Medicines, Human food, Water purification, Animal fodder, Alley cropping, Fertilizer, Living fence, Domestic cleaning agent, Fuel wood and many other uses (Agbogidi and Hondu, 2012).

- Moringa increased physical energy - Tune up body with naturally occurring nutrients so as to make energy last longer. Numerous research reports reveal that, parts of Moringa plant can be used in different techniques. Moringa oleifera seed and leaves is advantageous source of nutrients, medicines, clean dirty water and it can be used for alley cropping; because, it has lots of leafy material. The uses Moringa oleifera are well documented by Fahey, 2005 as nutritional, industrial, medicinal, and agricultural advantage.

- Moringa oleifera has great potential for prevention of different diseases like nutrient deficiency, cancer, anemia as well as for dirty water purification. Moringa powder contains sufficient amount of vitamins, nutrients and chemicals in it. This makes the tree a medicine for many different diseases (Gedefaw, 2015). Moringa oleifera has also been promoted by World Health Organization (WHO) as an alternative to imported food source to treat malnutrition (Sutalangka et al., 2013).

\section{Implications of Moringa tree to climate change mitigation}

- Climate change has a long-lasting impact on natural resources, economic activities, food security, health, society, and physical infrastructure and society in general. More than 
half of India's population of one billion people lives in rural areas and their livelihoods depend on climate-sensitive sectors such as agriculture, fisheries, and forestry. Hence, climate change adaptation measures are of national importance in order to ensure the protection of rural livelihoods, to preserve the countries natural resources, and to foster sustainable development.

- As indicated by Amaglo (2013), famine is connected to climate change and therefore, planting trees, which can sequester more carbon like Moringa tree, can play important role in climate change mitigation. Therefore, there is an urgent need to implement climate smart policies that can be built more salient food systems and combat climate change. There is great potential for the Moringa tree to not only store carbon, if it is grown on a much larger scale, but to improve the livelihoods of many farmers (Gedefaw, 2015). Moringa oleifera by Rockwood et al. (2013) shows that, Moringa contain nutritional value and can be used as bread, milk, spices, juices, sauces, tea and Moringa oleifera is a wonderful food tree with a significant source of vitamin $\mathrm{C}$, calcium, proteins and Iron.

- Research report by Rockwood et al. (2013) confirmed that, Moringa oleifera dry leaves contain nine times proteins than yogurt, ten times vitamin A than carrot, twenty five times iron than spinach, fifteen times potassium than bananas, seventeen times calcium than in milk and seven times more vitamin $\mathrm{C}$ than orange. Because of high nutritive value and rich source of protein Moringa leaves are suggested by doctors, nutritionists and community health workers to cope with the problems of malnutrition worldwide (Razis et al., 2014; Dhakar et al., 2011; Thurber and Fahey, 2010).

- In developing country climate change is affecting to small holder farmers who dominate the agriculture sector. The study on the opportunities for linking adaptation and mitigation in Agroforestry systems indicated that, the impacts of climate change are handled at the level of natural resource base upon which smallholder farmers depend, at the individual and farming system level (Vershot et al., 2005). The research reported on the environmental and medicinal value analysis of Moringa oleifera specified that, Farmers need to formulate adaptation strategies and mechanisms to reduce the climate change impacts (Gedefaw, 2015). To combat efficient for climate change mitigation and food shortages it is good to look at the potential that is already available in developing and third world countries. Moringa is therefore a very simple and readily available solution. Moringa oleifera is called a "Never Die" plant because of its adaptability to weather, soil and other environmental vagaries according to Fuglie (2000). There is clear evidence that Moringa oleifera is, no doubt, a suitable crop for climate change mitigation because of its high level of adaptability and numerous nutritional, medicinal, agricultural, domestic and industrial values (Ndubuaku et al., 2014).

- The heavy flushes produced by the trees even during the dry season act as good sink for carbon dioxide absorption and utilization, thus reducing the level of atmospheric carbon dioxide which is one of the major courses of ozone layer depletion and global warming. Moringa tree is a climate-change-adaptable crop for life sustenance against food insecurity threats (Ndubuaku et al., 2014).

- Large production of the trees is, therefore, advocated especially amongst the women. It does not only add to the home-use foodstuff but also creates job opportunities for women and their children for their capacity building. It reduces death toll due to malnutrition and diseases (Ndubuaku et al., 2014). The ability of the tree to mitigate the effects of climate change is also impressive.

- According to the study of Villafuerte (2009) the rate of Moringa tree to absorb carbon dioxide $\left(\mathrm{CO}_{2}\right)$ is fifty times $(50 \times)$ higher when compared to the Japanese cedar tree and also twenty times $(20 \times)$ higher than that of general vegetation. Study on Moringa and global warming revealed that, 1 person emits $320 \mathrm{~kg}$ of $\mathrm{CO}_{2}$ /year; it takes 23 Japanese Cedar trees takes 50 years to absorb this amount of $\mathrm{CO}_{2}$; it takes 2 Moringa trees 2 years to absorb this amount and 1 family car emits $2300 \mathrm{~kg}$ of $\mathrm{CO}_{2} /$ year; it takes 160 Japanese Cedar trees 50 years to absorb this amount of $\mathrm{CO}_{2}$; it takes 10 Moringa trees 2 years (Ndubuaku et al., 2014). Therefore, Moringa tree is useful tool in the prevention of global warming; because it sequesters more carbon with its all parts. Therefore, planting such important tree in different parts of the 
country will mitigate the impacts of climate change (Daba, 2016).

\section{* Ethnomedicinal potential of Moringa}

\section{Traditional uses}

- The plant is used as antispasmodic, stimulant, expectorant and diuretic. Fresh root is acrid and vesicant (has the taste of horse-radish). Internally it is used as stimulant, diuretic and antilithic. Gum is bland and mucilaginous. Seeds are acrid and stimulant. Bark is emmenogogue and even abortifacient, antifungal, antibacterial. Flowers are cholagogue, stimulant, tonic and diuretic and useful to increase the flow of bile. The plant is also a cardiac circulatory tonic and antiseptic (Nadkarni, 2009).

- Pods are antipyretic, anthelmintic; fried pods are used in diabetes. Root juice is employed in cardiac tonic, antiepileptic. Used for nervous debility, asthma, enlarged liver and spleen, deep- seated inflammation and as diuretic in calculus affection. Decoction is used as a gargle in hoarseness and sore throat. Root and fruit are antiparalytic. Leaf juice is used in hiccough (emetic in high doses); cooked leaves are given in influenza and catarrhal affections. Root-bark is used as antiviral, antiinflammatory, analgesic. Stem-bark and flowers are hypoglycaemic (Mishra et al., 2011).

- Infusion of seed is anti-inflammatory, antispasmodic and diuretic, also given in venereal diseases (Mishra et al., 2011).

- Along with other therapeutic applications, The Ayurvedic Pharmacopoeia of India indicated the use of the dried root bark in goitre, glycosuria and lipid disorders (also dried seeds), and leaf, seed, root bark and stem bark in internal abscess, piles (Khare, 2007).

- Dosage: Leaf-10-20ml. juice; root bark-2-5 g powder; stem bark-2-5g powder; seed-5- $10 \mathrm{~g}$ powder. Leaf, flower, fruit, seed, bark, root-1-3 g powder; 50-100 ml decoction (The Ayurvedic Pharmacopoeia of India Vol IV\& VII).

\section{Medicinal uses of Moringa}

- Moringa has long been used in herbal medicine in India as well as Africa. Moringa oleifera is often referred as a panacea and can be used to cure more than 300 diseases. Different studies shown that, all parts of Moringa oleifera (leaves, fruits, immature pods, and flowers) are incorporated into the traditional food of humans in many tropical and subtropical countries.

\section{$>$ Medicinal uses of all parts of Moringa}

- Various parts of Moringa tree act as cardiac and possess antitumor, circulatory stimulants, antiepileptic, antipyretic, antiulcer, antiinflammatory, antispasmodic, anti-hypertensive, diuretic, antioxidant, anti-diabetic, cholesterol lowering, antibacterial, hepato-protective and antifungal activities.

- Leaves: Moringa leaves are the most commonly used part of the plant. Moringa leaves treat hyperglycemia, asthma, flu, heart burn, Dyslipidemia, malaria, syphilis, diarrhea, pneumonia, scurvy, headaches, bronchitis, skin diseases, eye and ear infections. Alsoreduces, blood pressure and cholesterol and acts as an anticancer, Antioxidant, antimicrobial, antiatherosclerotic and ant diabetic agents, neuroprotectant (Rockwood et al., 2013; Mibikay, 2002; Fuglie, 2005; Ijartini, 2003; Choudhary et al., 2013; Jung, 2014).

- Seeds: Numerous researches reported that, Moringa seed powder can be used as for cleaning dirty water in a simple and quick method. Seeds of Moringa help in treating Chrohn's disease, hyperthyroidism, rheumatism, antiherpes- simplex virus arthritis, cramp, epilepsy gout, and sexually transmitted diseases, can act as antimicrobial and anti-inflammatory agents (Rockwood et al., 2013; Thurber and Fahey, 2010; Kasolo et al., 2010; Nair and Varalaxmi, 2011; Sutalangka et al., 2013).

- Root: Root bark acts as an anti-ulcer, antiinflammatory and cardiac stimulant agent (Choudary et al., 2013; Sreelatha and Padma, 2009; Monera and Mopanga, 2012).

- Flower: Many scholars shown that Moringa flowers act as anti-arthritic; hypocholesterolemic agents can cure urinary and cold problems (Fuglie, 2005; Sutalangka et al., 2013)

- Pods: Moringa pods treat liver, diarrhea and spleen problems, and joint pain (Rockwood et al., 2013; Kasolo et al., 2010).

- Many natural foods will have many health benefits, such as providing beneficial nutrition. Some foods that much more are known as superfoods. Moringa is one type of superfood that 
is beginning to see a lot more exposure. There are many benefits of drinking Moringa which might be surprising. Moringa is a traditional remedy which has been used for generations in Eastern cultures. This is why we need to seriously look at the benefits of drinking Moringa as a dietary supplement and health aid.

- Common diseases like diabetes and heart disease can be prevented by drinking Moringa as a tea. The health benefits of drinking Moringa should be enough for us to add it as a supplement to any other health aids. It is much better for our health than drinking green or any herbal tea daily. Moringa is also perfect as an ingredient when we want to make a smoothie.

- Moringa plant is beginning to gain more popularity as a new "superfood" for its highly nutritious profile and powerful anti-inflammatory, antioxidant, and tissue-protective properties among many other health benefits.

- It has been used for generations in Eastern countries to treat and prevent diseases such as diabetes, heart disease, anemia, arthritis, liver disease, and respiratory, skin, and digestive disorders. Moringa has become popular as a natural leaf powder supplement, although the pods, roots, bark, flowers, seeds, and fruits are also edible.

- It is used as a traditional remedy for many ailments, and here are few scientifically backed health benefits of consuming the Moringa leaf. Moringa use as medicinal and nutritional purposes was started since centuries (Mahmood et al., 2010). Moringa oleifera contains all the essential medicinal and nutritional properties and an extremely valuable food source that are vital for human and livestock consumptions (Mahmood et al., 2010; Duke, 1987; Fuglie, 1999, 2000; Babu, 2000; Razis et al., 2014; Ali et al., 2015).

\section{Moringa is nutrient-packed}

- Moringa is a rich source of vitamins, minerals, and amino acids. It contains significant amounts of vitamin $\mathrm{A}, \mathrm{C}$, and $\mathrm{E}$; calcium; potassium; and protein.

\section{Moringa fights free radicals}

- Antioxidants fight free radicals, molecules that cause oxidative stress, cell damage, and inflammation.

- Moringa contains antioxidants called flavonoids, polyphenols, and ascorbic acid in the leaves, flowers, and seeds.

- The leaf extracts had higher antioxidant activity, free-radical-scavenging capacity, and higher inhibition of lipid, protein, and DNA oxidation than flowers and seeds. This means it prevents the damage and degradation that free radicals cause in the cells of different organs in the body, keeping them healthy and functioning at their best.

\section{Moringa fights inflammation}

- Inflammation can lead to chronic diseases like diabetes, respiratory problems, cardiovascular disease, arthritis, and obesity. Moringa reduces inflammation by suppressing inflammatory enzymes and proteins in the body, and moringa leaf concentrate can significantly lower inflammation in the cells.

\section{Moringa reduces some diabetes symptoms}

- Moringa leaf powder has been effective at reducing lipid and glucose levels and regulating oxidative stress in diabetic patients, which means it lowers blood sugar and cholesterol and improves protection against cell damage.

\section{Moringa protects the cardiovascular system}

- Moringa leaf powder has heart-healthy benefits, particularly in blood lipid control, the prevention of plaque formation in the arteries, and reduced cholesterol levels.

\section{Moringa supports brain health}

- Moringa supports brain health and cognitive function because of its antioxidant and neuroenhancer activities. It's also been tested as a treatment for Alzheimer's disease with favorable preliminary results.

- Its high content of vitamins $\mathrm{E}$ and $\mathrm{C}$ fight oxidation that leads to neuron degeneration, improving brain function. It's also able to normalize the neurotransmitters serotonin, dopamine, and noradrenaline in the brain, which play a key role in memory, mood, organ function, responses to stimulus such as stress and 
pleasure, and mental health, for example in depression and psychosis.

\section{$>$ Moringa protects the liver}

- Moringa contains high concentrations of polyphenols in its leaves and flowers that protect the liver against oxidation, toxicity, and damage.

- Moringa can reduce liver damage and fibrosis and reverse oxidation in the liver. Moringa oil can also restore liver enzymes to normal levels, reducing oxidative stress, and increasing protein content in the liver.

- The liver is responsible for blood detoxification, bile production, fructose metabolism, fat metabolism, and nutrient processing, and it can only fulfill these functions with the aid of liver enzymes, so it's vital they stay at normal levels. For instance, lower levels of hepatic enzymes can impair its ability to filter the blood.

\section{Moringa contains antimicrobial and antibacterial properties}

- Moringa has antibacterial and anti-fungal properties that fight infections. It's been effective against types of fungi that cause infections on skin and strains of bacteria responsible for blood and urinary tract infections and digestive problems.

\section{$>$ Moringa enhances wound healing}

- Moringa has blood-clotting properties in its leaves, roots, and seeds that benefit wound healing and can reduce clotting time, which means it reduces the time it takes for scratches, cuts, or wounds to stop bleeding include (Kumar and Gopal, 1999).

\section{$>$ How to use it}

- We can add Moringa powder to your smoothie or drink it as a tea. The leaf powder was deemed safe in human studies, even in larger doses than normal. The powder has a mild flavor, so it makes for a light Moringa tea with a slightly earthy taste.

- Moringa can have laxative effects in large quantities, so a safe dose to introduce it into your food or diet and avoid digestive problems is $1 / 2$ to 1 teaspoon per day.

\section{Ethnoveterinary potential of Moringa}

- Two hundred gm fine leaf paste is given twice daily for three to five days to cattle for quick relief from diarrhea and dysentery.

- The fine paste is prepared from five hundred gm pods and given for a month or so for the relief from rheumatism.

- The juice of the roots is applied on the ulcers of cattle for healing and removal of insect larvae (Mall and Tripathi, 2017).

\section{Conclusion}

More Moringa oleifera tree is indeed a miracle tree with enormous potentials yet to be fully explored in medicinal and food application. All parts of Moringa oleifera tree is said to have useful assets that can help humankind.

This study has tried to reviews a multipurpose uses of Moringa oleifera and suggestion for the future mitigation of climate change. Numerous researchers concluded that, Moringa oleifera is a multipurpose tree and fast growing and well adapted to growing in adverse climate conditions and therefore, that is difficult to overlook in today's battle with the climate. Different studies reveal that, Moringa has a direct effect on agriculture, nutrition, health, water, environment, biodiversity and sanitation.

The latest research has documented that, Moringa oleifera is one of the medicine to reduce the occurrence of water borne disease which is on record as one of the main causes leading to high incidence of deaths in the developing countries. Thus, Moringa oleifera seeds are capable of appealing and sticking fast to bacteria and viruses that are found in contaminated and turbid water.

The capacity of the Moringa tree is inspiring in mitigating the adverse effects of climate change. The research report by Japanese has displayed that the rate of absorption of carbon dioxide $\left(\mathrm{CO}_{2}\right)$ by the Moringa tree is twenty times $(20 \times)$ higher than that of general vegetation. There is great potential for the Moringa tree to not only store carbon, but also to improve the livelihoods of many smallholder farmers. Therefore, planting of this tree in different parts of the country will mitigate the impacts of climate change.

Moringa oleifera really recognized to be a "Miracle tree", because it has multipurpose use for humankind and thus 
named as a nature gift at very low price. In order to discover and utilize full uses of this miracle tree, market development strategies, Strong policies, and research were required. Given its multiple uses and wide range of adaptability, Moringa is an ideal crop for sustainable food production that thrives as the climate changes. Generally, Moringa oleifera offers very interesting opportunities for small holder farmers as food supplement, medicine, nutrition, water treatment, livestock feed, vegetable, oil, foliar spray, green manure, natural fertilizer, cosmetic, fooder, care products, soil and water conservation and reduce greenhouse gas emission.

Dr. M. S. Swaminathan says that the most urgent task today is the conservation of diversity and pluralism in all living organisms ranging from microbes to man. In particular, we need to promote gene bank for a warming planet. In this connection, the following three kinds of community gene banks developed by M. S. Swaminathan Research Foundation (MSSRF) are worthy of replication. The first one is Genetic Garden of halophytes, the second one is Genetic Garden of biofortified plants species like Moringa, sweet potato, etc. which for helping to find agricultural remedies for prevailing nutritional maladies, in particular micronutrient dificiencies like Vitamin A, Vitamin $\mathrm{B}_{12}$, Zinc, Iron, etc and the third one is Farm Gene bank for the in situ conservation (Swaminathan, 2016). We do remember the deliberations of Dr. M. S. Swaminathan in the Inaugural function on $1^{\text {st }}$ International Agrobiodiversity Congress held on 6-9 November, 2016, at Vigyan Bhawan, New Delhi which was inaugurated by our Prime Minister Sri Narendra Modi. During his talk Dr. Swaminathan remembered at least ten times the Moringa and its multipurpose uses with greater emphasis regarding its positive role to weed out malnutrition and about its multiplication as well as its conservation.

Moringa should be promoted for further consumption to improve nutrition and medicinal functions and as well as for climate change mitigation.

\section{Conflict of interest statement}

Authors declare that they have no conflict of interest.

\section{References}

Adeyemi, O.S., Elebiyo, T.C., 2014. Moringa oleifera supplemented diets prevented nickel induced nephro toxicity in Wistar rats. J. Nutr. Metab. 2014, 1-8.

Alam, M., Alam, M., Hakim, M., Abdul, H., Obidul, A., 2014. Development of fiber enriched herbal biscuits: a preliminary study on sensory evaluation and chemical composition. Int. J. Nutr. Food Sci. 3, 246250.

Ali, E.N., Alfarra, S.R., Yusoff, M.M., Rahman, M.L., 2015. Environmentally friendly biosorbent from Moringa oleifera leaves for water treatment. IJESD. 6, 165-169.

Amaglo, N., 2006. Moringa and other highly nutritious plant resources: Strategies, standard and markets for a better impact on nutrition in Africa. Accra, Ghana.

Amaglo, N., 2013. Moringa as a climate change mitigation strategy. Hunan Agriculture University, Faculty of Food Science and Technology, Changsha, Hunan. China 410128.

Anhwange, B.A., Ajibola, V.O., Oniye, S. J., 2004 Chemical studies of the seeds of Moringa oleifera (Lam.) and Detarium microcarpum (Guill and Sperr). J. Biol. Sci. 4, 711-715.

Anwar, F., Rashid, U., 2007a. Physico-chemical characteristics of Moringa oleifera seeds and seed oil from a wild provenance of Pakistan. Pak. J. Bot. 39, 1443-1453.

Anwar, F., Latif, S., Ashraf, M., Gilani, A.H., $2007 \mathrm{~b}$. Moringa oleifera: A food plant with multiple biochemical and medicinal uses. Phytother. Res. 21, 17-25.

Arise, A., Arise, R., Sanusi, M., Esan, O., Oyeyinka, S., 2014. Effect of Moringa oleifera flower fortification on the nutritional quality and sensory properties of weaning food. Croat. J. Food Sci. Technol. 6(2), 6571.

Arora, D.S., Onsare, J.G., Kaur, H., 2013. Bioprospecting of Moringa (Moringaceae): Microbiological perspective. J. Pharmacog. Phytochem. 1, 193-215.

Basra, S.M.A., Ashfaq, U., 2012. Moringa: A miracle plant of agro-forestry. J. Agric. Soc. Sci. 8, 115-122.

Babayeju, A., Gbadebo, C., Obalowu, M., Otunola, G., Nmom, I., 2014. Comparison of organoleptic properties of egusi and eforiro soup blends produced with Moringa and spinach leaves. Food Sci. Qual. Manag. 28, 15-18.

Babu, S.C., 2000. Rural nutrition interventions with indigenous plant foods: A case study of vitamin deficiency in Malawi. Agron. Soc. Environ. 4, 169179.

Baumer, M., 1983. Notes on Trees and Shrubs in Arid and Semi-arid Regions. FAO, EMASAR Phase II, 
Rome.

Bose, B., 1980. Enhancement of nodulation of Vigna mungo by ethanolic extract of moringa leaves - A new report. Nat. Acad. Sci. Lett. 3, 103-104.

Chawla, S., Saxena, A., Seshadri, S., 1988. In-vitro availability of iron in various green leafy vegetables. J. Sci. Food Agric. 46, 125-127.

Chinma, C., Abu, J., Akoma, S., 2014. Effect of germinated tigernut and Moringa flour blends on the quality of wheat-based bread. Food Process Preserv. 38, 721-727.

Choudhary, M.K., Bodakhe, S.H., Gupta, S.K., 2013 Assessment of the anti-ulcer potential of Moringa oleifera root-bark extract in rats. J. Acupunct. Merid. Stud. 6, 214-220.

CSIR (Council of Scientific and Industrial Research), 1962. The Wealth of India. A Dictionary of Indian Raw Materials and Industrial Products. Raw Materials, Vol. 6. L-M, CSIR, New Delhi, India.

Daba, M., 2016. Miracle tree: A review on Multipurposes of Moringa olifera and its implications for climate change mitigation. J. Earth Sci. Climate Change. 7(8), 1000366.

Dahot, M.U., 1988. Vitamin contents of flowers and seeds of Moringa oleifera. Pak. J. Biochem. 21, 2124.

Dawit, S., Regassa, T., Mezgebu, S., Mekonnen, D., 2016. Evaluation of two Moringa species for adaptability and growth performance under Bako conditions. J. Natural Sci. Res. 6, 76-82.

Delaveau, P., Botteau, P., 1980. Huiles à interet pharmacologique, cosmetologique et dietique. IV. Huiles de Moringa oleifera Lamk. et de $\mathrm{M}$. Drouhardii Jumelle. Plant. Med. Phytother. 14, 2933.

Demeulenaere, E., 2001. Moringa stenopetala, a subsistence resource in the Konso district. Proceedings of the International Workshop Development Potential for Moringa Products, October 29-November 2, 2001, Dar-Es-Salaam, Tanzania. pp.2-29.

Dhakar, R. C., Maurya, S.D., Pooniya, B.K., Gupta, B.N., Sanwarmal, M., 2011. Moringa: The herbal gold to combat malnutrition. Chron. Young Scientists. 2, 119-125.

Dogra, P.D., Singh, B.P., Tandon, S., 1975. Vitamin content in Moringa pod vegetable. Curr. Sci. 44, 31.

Duke, J.A., 1987. Moringaceae: Horseradish-tree, benzolive - tree, drumstick-tree, sohnja, moringa, murunga-kai, malunggay. pp.19-28. In: Moringa: A multipurpose vegetable and tree that purifies water
(Ed.: Benge, M.). Sci. \& Technol/For. Environ. \& Natural Resources Agro- Forestation Tech. Ser. 27. US AID, Washington, DC.

ECHO, 2009. Educational Concerns for Hunger Organization (ECHO's) Moringa Technical Note. USA.

Fahey, J. W., 2005. Moringa oleifera: A review of the medical evidence for its nutritional, therapeutic and prophylactic properties. Trees Life J. 1, 5.

Ferrao, A.M.B.C., Mendez Ferrao, J.E., 1970. Acidos gordos em oleo de Moringueiro (Moringa oleifera Lam.). Agron. Angolana. 8, 3-16.

Foidl, N., Harinder, P.S., Markar, P., Becker, K., 2001. The potential of Moringa oleifera for agricultural and industrial uses. In: The Miracle Tree (Eds.: Lowell, J., Fuglie, Darkar Senegal). pp.45-76.

Francis John, K., Liogier, H.A., 1991. Naturalized exotic tree species in Puerto Rico. Gen. Tech. Rep. SO-82. New Orleans, LA: U.S. Department of Agriculture, Forest Service, Southern Forest Experiment Station.

Fuglie, L.J., 2003. The Moringa Trees - A Local Solution to Malnutrition. Dakar, Senegal.

Fuglie, L. J., 2005. The Moringa Tree: A Local Solution to Malnutrition Church World Service in Senegal.

Fuglie, L.J., 1999. The Miracle Tree: Moringa oleifera: Natural Nutrition for the Tropics. Church World Service, Dakar. 68p. Revised in 2001 and published as The Miracle Tree: The Multiple Attributes of Moringa. 172p.

Fuglie, L.J., 2000. New Uses of Moringa Studied in Nicaragua. ECHO Development Notes No. 68.

Gassenschmidt, U., Jany, K. D., Tauscher, B., Niebergall, H., 1995. Isolation and characterization of a flocculating protein from Moringa oleifera Lam. Biochim. Biophys. Acta. 1243, 477-481.

Gedefaw, M., 2015. Environmental and medicinal value analysis of Moringa (Moringa oleifera) tree species in Sanja, North Gondar, Ethiopia. AIJCSR-480. 2, 20-35.

Hekmat, S., Morgan, K., Soltani, M., Gough, R., 2015 Sensory evaluation of locally-grown fruit purees and inulin fibre on probiotic yogurt in Mwanza, Tanzania and the microbial analysis of probiotic yogurt fortified with Moringa oleifera. J. Health Popul. Nutr. 33, 60-67.

Holmes, R. G. H., Travis, V. E., Sutherland, J.P., Folkard, G. K., 1994. The use of natural coagulants to treat waste waters for agricultural reuse in developing countries. Sci. Technol. Develop. 12, 1523.

Ijarotimi, O.S., Adeoti, O., Ariyo, O., 2013. 
Comparative study on nutrient composition, phytochemical, and functional characteristics of raw, germinated, and fermented Moringa oleifera seed flour. Food Sci. Nutr. 1, 452-463.

Jahn, S.A., Musnad, H.A., Burgstaller, H., 1986. Tree that purifies water: Cultivating multipurpose Moringaceae in the Sudan. Unasylva. 38, 23-28.

Jiru, D., Sonder, K., Alemayehu, L., Mekonen, Y., Anjulo, A., 2006. Leafy Yield and Nutritive Value of Moringa stenopetala and Moringa oleifera Accessions: Its Potential Role in Food Security in Constrained Dry Farming Agro-forestry Systems. Addis Ababa, Ethiopia.

Jongrungruangchok, S., Bunrathep, S., Songsak, T., 2010. Nutrients and minerals content of eleven different samples of Moringa oleifera cultivated in Thailand. J. Health Res. 24, 123-127.

Jung, I.L., 2014. Soluble extract from Moringa oleifera leaves with a new anti-cancer activity. PlosOne. 9, 1-10.

Karim, O., Kayode, R., Oyeyinka, S., Oyeyinka, A., 2015. Physico-chemical properties of stiff dough 'amla' prepared from plantain (Musa paradisca) flour and Moringa (Moringa oleifera) leaf powder. Food Health Dis. 4, 48-58.

Karim, O. R., Kayode, R. M. O., Oyeyinka, S. A., Oyeyinka, A. T., 2013. Proximate, mineral and sensory qualities of 'amla' prepared from yam flour fortified with moringa leaf powder. Food Sci. Qual. Manag. 12, 10-22.

Kasolo, J.N., Bimenya, G.S., Ojok, L., Ochieng, J., Ogwal-okeng, J. W., 2010. Phytochemicals and uses of Moringa oleifera leaves in Ugandan rural communities. J. Med. Plants Res. 4, 753-757.

Khare, C. P., 2007. Indian Medicinal Plants. Springer. pp.422-423.

Kolawole, F., Balogun, M., Opaleke, D., Amali, H., 2013. An evaluation of nutritional and sensory qualities of wheat-moringa cake. Agro-search. 13, 87-94.

Koul, B., Chase, N., 2015. Moringa oleifera Lam.: Panacea to several maladies. J. Chem. Pharmaceut. Res. 7, 687-707.

Kuikman, M.O., Connor, C.P., 2015. Sensory evaluation of Moringa-probiotic yoghurt containing banana, sweet potato or avocado. J. Food Res. 4, 165-171.

Mahmood, K.T., Mugal, T., Haq, I.U., 2010. Moringa oleifera: A natural gift- A review. J. Pharm. Sci. Res. 2, 775-781.

Makkar, H.P.S., Becker, K., 1996. Nutritional value and antinutritional components of whole and ethanol extracted Moringa oleifera leaves. Anim. Feed Sci. Technol. 63, 211-228.

Makkar, H.P.S., Becker, K., 1997. Nutrients and antiquality factors in different morphological parts of Moringa oleifera tree. J. Agric. Sci. 128, 311-322.

Mall, T.P., Tripathi, S.C., 2017. Diversity of nutrimental and ethnoveterinary therapeutic potential plants of Bahraich (UP) India. World J. Pharmaceut. Res. 6(1), 1032-1063.

Mibikay, M., 2012. Therapeutic potential of Moringa oleifera leaves in chronic hyper glycemia and dyslipidemia: A review. Front. Pharmaco. 13, 1-12.

Melesse, A., Tiruneh, W., Negesse, T., 2011. Effects of feeding Moringa stenopetala leaf meal on nutrient intake and growth performance of Rhode Island Red chicks under tropical climate. Trop. Subtrop. Agro Ecosyst. 14, 485-492.

Mishra, G., Singh, P., Verma, R., Kumar, S., Srivastava, S., Jha, K.K., Khosa, R.L., 2011. Traditional uses, phytochemistry and pharmacological properties of Moringa oliefera plant: An overview. Der. Pharmacia Lett. 3(2), 141-164.

Monera, T.G., Maponga, C.C., 2012. Prevalence and patterns of Moringa oleifera use among HIV positive patients in Zimbabwe: A cross-sectional survey. J. Public Health Afr. 3, 6-8.

Morton, J.F., 1991. The horseradish tree, Moringa pterygosperma (Moringaceae) - A boon to arid lands. Econ. Bot. 45, 318-333.

Moyo, B., Masika, P., Hugo, A., Muchenje, V., 2011. Nutritional characterization of Moringa (Moringa oleifera Lam.) leaves. Afr. J. Biotechnol. 10, 1292512933.

Nadkarni, K. M., 2009. Indian Materia Medica. Bombay Popular Prakashan. Vol. I. pp.811-816.

Nair, S., Varalakshmi, K.N., 2011. Anticancer, cytotoxic potential of Moringa oleifera extracts on HeLacellline. J. Nat. Pharm. 2, 138-142.

Ndubuaku, U.M., Ndubuaku, T.C., Ndubuaku, N.E., 2014. Yield characteristics of Moringa oleifera across different ecologies in Nigeria as an index of its adaptation to climate change. Sustain. Agric. Res. 3(1), 95-100.

Odee, D., 1998. Forest biotechnology research in drylands of Kenya: The development of Moringa species. Dryland Biodiv. 2, 7-8.

Palada, M.C., Chang, L.C., 2003. Suggested Cultural Practices for Moringa, International Corporation Guide, AVRDC, Shanhua, Taiwan.

Rahmani, A.H., 2015. Cassia fistula Linn: Potential candidate in the health management. Pharmacogn. 
Res. 7(3), 217-224.

Ramachandran, C., Peter, K.V., Gopalakrishnan, P.K., 1980. Drumstick (Moringa oleifera): A multipurpose Indian vegetable. Econ. Bot. 34, 276283.

Razis, A.F.A., Ibrahim, M.D., Kntayya, S. B., 2014. Health benefits of Moringa oleifera. Asian Pac. J. Cancer Prev. 15, 8571-8576.

Rockwood, J.L., Anderson, B.G., Casamatta, D.A., 2013. Potential uses of Moringa oleifera and an examination of antibiotic efficacy conferred by Moringa oleifera seed and leaf extracts using crude extraction techniques available to under-served indigenous populations. Int. J. Phytothear. Res. 3, 61-71.

Saini, R., Manoj, P., Shetty, N., Srinivasan, K., Giridhar, P., 2014. Dietary iron supplements and Moringa oleifera leaves influence the liver hepcidin messenger RNA expression and biochemical indices of iron status in rats. Nutr. Res. 34, 630-638.

Salem, A.S., Salama, W.M., Hassanein, A.E., Ghandour, H., 2013. Enhancement of nutritional and biological values of Labneh by adding dry leaves of Moringa oleifera as innovative dairy products. World Appl. Sci. J. 22, 1594-1602.

Siddhuraju, P., Becker, K., 2003. Antioxidant properties of various solvent extracts of total phenolic constituents from three different agro-climatic origins of drumstick tree (Moringa oleifera Lam.). J. Agric. Food Chem. 15, 2144-2155.

Sreelatha, S., Padma, P.R., 2009. Antioxidant activity and total phenolic content of Moringa oleifera leaves in two stages of maturity. Plant Foods Human Nutr. 64, 303-311.

Stevens, G., Baiyeri, K., Akinnnagbe, O., 2013. Ethnomedicinal and culinary uses of Moringa oleifera Lam. in Nigeria. J. Med. Plants Res. 7, 799-804.

Sutalangka, C., Wattanathorn, J., Muchimapura, S., Thukham-mee, W., 2013. Moringa oleifera mitigates memory impairment and neurodegeneration in animal model of age-related dementia. Oxid. Med. Cell Longev. 2013, 1-9.

Sutherland, J. P., Folkard, G.K., Grant, W. D., 1989.
Seeds of Moringa species as naturally occurring flocculants. SciTech. Develop. 7, 191-197.

Swaminathan, M.S., 2016. Agrobiodiversity and Achieving the Zero Hunger Challenge. Indian J. Plant Genet. Resour. 29(3), 249-250 (A special issue devoted to 1st International Agrobiodiversity Congress).

Tauscher, B., 1994. Water treatment by occulant compounds of higher plants. Plant Res. Develop. 40, 56-70.

The Ayurvedic Pharmacopoeia of India, Department of Indian System of Medicine \& Homeopathy, New Delhi Part I- IV-124-131.

The Ayurvedic Pharmacopoeia of India, Department of Indian System of Medicine \& Homeopathy, New Delhi Part I- VII-155-157.

Thurber, M.D., Fahey, J.W., 2010. Adoption of Moringa oleifera to combat under-nutrition viewed through the lens of the diffusion of innovations theory. Ecol. Food Sci. Nutr. 48, 1-13.

Vershot, L.V., Mackensen, J., Kaadji, S., Noordwijik, M., Tomich, T., 2005. Opportunities for Linking Adaptation and Mitigation in Agroforestry Systems. http://www.worldagroforestry.org/downloads/Public ations/PDFS/bc04241.pdf. pp.103-121.

Villafuerte, L. R., Villafurte-Abonal, L., 2009. Data taken from the Forestry Agency of Japan in Moringa. Malunggay Phillippines, Apples of Gold Publishing, Singapore. 240p.

Yameogo, C.W., Bengaly, M.D., Savadogo, A., Nikiema, P.A., Traore, S.A., 2011. Determination of chemical composition and nutritional values Moringa oleifera leaves. Pak. J. Nutr. 10, 264268.

Yisehak, K., Solomon, M., Tadelle, M., 2011. Contribution of Moringa (Moringa stenopetala Bac.), a highly nutritious vegetable tree, for food security in South Ethiopia: A review. Asian J. Appl. Sci. 4, 477-488.

Zarkadas, C.G., Yu, Z., Burrows, V.D., 1995. Protein quality of three new Canadian-developed naked oat cultivars using amino acid compositional data. J. Agric. Food Chem. 43, 415-421.

\section{How to cite this article:}

Mall, T. P., Tripathi, S.C., 2017. Moringa oleifera: A miracle multipurpose potential plant in health management and climate change mitigation from Bahraich (UP) India - An overview. Int. J. Curr. Res. Biosci. Plant Biol. 4(8), 52-66. doi: https://doi.org/10.20546/ijcrbp.2017.408.008 